\title{
Habitat preference by the Anatolian leopard (Panthera pardus tulliana Valenciennes, 1856) in North-eastern Anatolia, Turkey
}

\author{
Alptuğ Sarı ${ }^{1, *}$, Ebubekir Gündoğdu ${ }^{2}$, Şağdan Başkaya ${ }^{1}$ \& Ahmet Arpacık ${ }^{1}$ \\ ${ }^{1}$ Department of Wildlife Ecology and Management, Karadeniz Technical University, Trabzon, Turkey. \\ ${ }^{2}$ Department of Forest Engineering, Bursa Technical University, Bursa, Turkey. \\ ${ }^{*}$ Corresponding author: alptugsari@ktu.edu.tr
}

\begin{abstract}
This study aims to document the existence and habitat preferences of the Anatolian leopard (Panthera pardus tulliana Valenciennes, 1856) in north-eastern Anatolia, Turkey. We sampled eleven study areas in 2013-2017, primarily based on our previous field experiences, reports from local people, and literature. Based on the findings from initial surveys, camera traps and leopard studies were mostly used in parts of the Giresun (Sarıçiçek Mountain), Erzincan (Sansa Strait), and Bingöl (Yedisu Valley) Provinces. We employed both direct observations and indirect observations. A total of 58 observations were recorded, ranging from 1176-3050 meters in altitude: six camera trap pictures, three thermal video camera images, three sightings by local people, 28 sets of tracks, 13 pieces of scat, two ground-scrapings, and three tree-scratches belonging to the Anatolian leopard. We defined eight habitat types and found that leopards preferred sparse forest areas, rocky habitats, and agriculture and pasture regions the most. Furthermore, 49 of 58 observations made in the sampling areas were detected in the southerly aspects of the study region. The Anatolian leopard habitat selection is mainly based on prey abundance, and we found that leopards prefer wild boar (Sus scrofa) the most, followed by wild goat (Capra aegagrus), chamois (Rupicapra rupicapra), and roe deer (Capreolus capreolus).
\end{abstract}

Keywords. Camera trap, habitat use, Anatolian leopard, Panthera pardus tulliana, thermal camera, Anatolia.

Sarı A., Gündoğdu E., Başkaya Ş \& Arpacık A. (2020). Habitat preference by the Anatolian leopard (Panthera pardus tulliana Valenciennes, 1856) in North-eastern Anatolia, Turkey. Belgian Journal of Zoology 150: 153-168. https://doi.org/10.26496/bjz.2020.78

\section{Introduction}

Predatory animals mostly choose habitats where they can meet their energy requirements (e.g., available prey) by spending minimum energy and minimize life-threatening risks (HAYWARD \& KERLEY 2005; HOPCRAFT et al. 2005). The leopard is a predator with one of the widest ranges of food sources in the world, and it can adapt to various climatic zones and ecological environments as long the quantity and quality of prey are high enough (BAILEY 1993; NOwELL \& JACKSON 1996; EDGAONKAR \& CHELLAM 2002). Generally, leopards prefer hilly or rocky, mountainous terrain interspersed with thick riverine vegetation and densely wooded areas. Leopard live in a wide variety of habitats, from semi-desert areas to evergreen forests, and has even been found near major metropolitan areas (BOTHMA \& LE RICHE 
1989). However, it is generally distributed in altitudes higher than 1000 meters above sea level. In these areas, they prefer the regions close to the water resources in the high parts of the mountains. Besides, in extremely arid regions, leopards prefer areas where there are plants such as acacia, sagebrush, and olive (JoHANY 2006). In the Great Caucasus Mountains, leopards prefer high mountainous areas habitats with grasslands, deciduous and mixed forests, and areas dominated by shrubs. In Dagestan, they live in sloping areas with snow-covered vegetation in the winter (LUKAREVSKY et al. 2007). Although coastal ecosystems are important hunting areas for leopards, they need more closed spaces for their hunting methods to be successful (KARANTH 1995). Leopards mostly lead nocturnal and regional lives; they are only seen in groups during breeding periods and when they raise their cubs (HAMILTON 1976). They use scents as the primary means of communication with each other especially during breeding periods (GREEN 1991; SUNQUIST \& SUNQUIST 2002). These scent sources include methods of marking with scats, scraping the ground, scratching trees, spraying urine, and rubbing objects in the area. These forms of communication are also used to mark their territory (SMITH et al. 1989).

The Anatolian leopard is the largest surviving cat species in Turkey. Among the most controversial topics in recent years is whether leopards live in Turkey, and if they do, what are the regions they live in, the properties of their habitats, and their overall number in Turkey. The number of subspecies of leopard living in the world is stated as eight in total in a comprehensive study (KITCHENER et al. 2017). The subspecies of leopard living in Turkey is the Anatolian leopard (P. pardus tulliana Valenciennes, 1856) (Kumerloeve 1956; Borner 1977; Ulrich 1994; KitChener et al. 2017). According to KumerLOEVE (1956) and Huş (1967), leopards were found in the Hopa and İspir regions in the Eastern Black Sea Region. The total number of leopards in Anatolia was estimated to be 13-14 individuals in 1974 (GÜRPINAR 1974) and 15-23 individuals in 1978 (GOODWIN \& HOLLOWAY 1978). BAŞKAYA \& BILGILI (2004) found leopards distributed in the Eastern Black Sea Mountains, including Ovit Mts. (Çapans Mts. 3274 m), Verçenik Mt. (3709 m), Kaçkar Mts. (3932 m), Altıparmak Mt. (3492 m), Yusufeli/Sukavuşumu $(500 \mathrm{~m})$ and Karçal Mt. $(3415 \mathrm{~m})$. The habitats in which they found leopard footprints ranged from pseudo-maquis (Egbribakacak Hill, $1200 \mathrm{~m}$ ) to dense forest (ÇamdalI Yayla, $1700 \mathrm{~m}$ ), upper forest (Kito Yayla, $2000 \mathrm{~m}$ ), and the alpine zone (Adsiz Göl, $3300 \mathrm{~m}$ ). However, the habitat use of the animal appears to be strongly associated with the movements of its prey and human disturbance. According to CAN (2004), there is no hard evidence for the presence of leopards in the Turkish part of the Caucasus eco-region. LUKAREVSKY et al. (2007) did not confirm the presence of leopards in northeastern Turkey during a field trip to the Turkish part of the Caucasus eco-region in 2003 (Ikizdere, Sivrikaya, and Kiliçkaya, and Cevreli and Yusufeli in the basin of the Çoruh River), but their study period was short.

This paper presents new data documenting the existence and habitat preferences of the Anatolian leopards in northeastern Anatolia, correlates the leopard's presence with some selected ecological and environmental parameters, and recommends conservation strategies for these extremely endangered species.

\section{Materials and methods}

\section{Study Area}

The study was conducted between April 2013 and December 2017 in northeastern Anatolia, Turkey. We used our previous leopard studies, reports from local people, and hunting and sighting records in Turkey over recent years to determine a study area. Accessibility to researchers was also taken into account, as the authors would have to be able to navigate the area to set up camera traps. Northeastern Anatolia was selected because this is where the highest number of shootings and sightings has been recorded over the last 50 years. The sampling areas were located between $38^{\circ} 47^{\prime} 36^{\prime \prime}-38^{\circ} 21^{\prime} 30^{\prime \prime} \mathrm{N}$ and $37^{\circ} 37^{\prime} 56^{\prime \prime}-$ $44^{\circ} 17^{\prime} 28^{\prime \prime}$ E (Fig. 1). 
We sampled 11 areas with a total area of $4650 \mathrm{~km}^{2}$ (Table 1). Based on the findings from initial surveys, camera traps and leopard studies were mostly concentrated in parts of the Giresun (Sarıçiçek Mountain), Erzincan (Sansa Strait), and Bingöl (Yedisu Valley) Provinces. These three provinces form a NorthSouth cross-section, thus making them a suitable representation of Northeastern Anatolia.

The study area contains rich water resources, including much of the catchment from the Çoruh, Aras, Kura, Murat, and Firat Rivers. This region, the most mountainous region in Turkey, includes a variety of suitable ecosystems for leopards such as forest, high mountain forest, alpine, steppe, high mountain plains, deep river valleys, rocky areas, agricultural areas, pastures, and high mountain grasslands (Fig. 2).

Important mountains in the study area include: Ağrı Mountain (Mt.) (5137 m), Süphan Mt. (4058 m), Kaçkar Mt. (3932 m), Verçenik Mt. (3711 m), Altıparmak Mt. (3562 m), Tendürek Mt. (3584 m), Keşiş Mt. (3546 m), Munzur Mt. (3449 m), Karçal Mt. (3415 m), Abdal Musa Mt. (3331 m), Cankurtaran hill (3278 m), Palandöken Mt. (3271 m), Bingöl Mt. (3250 m), Gavur Mt. (3248 m), Yalnızçam Mt. (3202 m), Göze Mt. (3167 m), Şeytan Mt. (2906 m), Soğanlı Mt. (2896 m) and Sesödile Mt. (2438 m).

Besides offering important habitats for leopards, the study area includes a wide range of prey, with intensive populations of mammals such as wild goat (Capra aegagrus), chamois (Rupicapra rupicapra), wild boar (Sus scrofa), red deer (Cervus elaphus) and roe deer (Capreolus capreolus). European hares (Lepus europeus) also provide an alternative prey base for leopards within the study areas, along with game birds such as chukar partridge (Alectoris chukar) and grey partridge (Perdix perdix). Besides, carnivorous mammal species such as the grey wolf (Canis lupus), Eurasian lynx (Lynx lynx), brown bear (Ursus arctos), golden jackal (Canis aureus), red fox (Vulpes vulpes) and hyena (Hyaena hyaena) were also identified. Tree species include Scotch pine (Pinus sylvestris), oriental spruce (Picea orientalis), oriental beech (Fagus orientalis), oak (Querqus spp.), birch (Betula spp.), juniper (Juniperus spp.), poplar (Populus spp.), and willow (Salix spp.) trees along river banks.

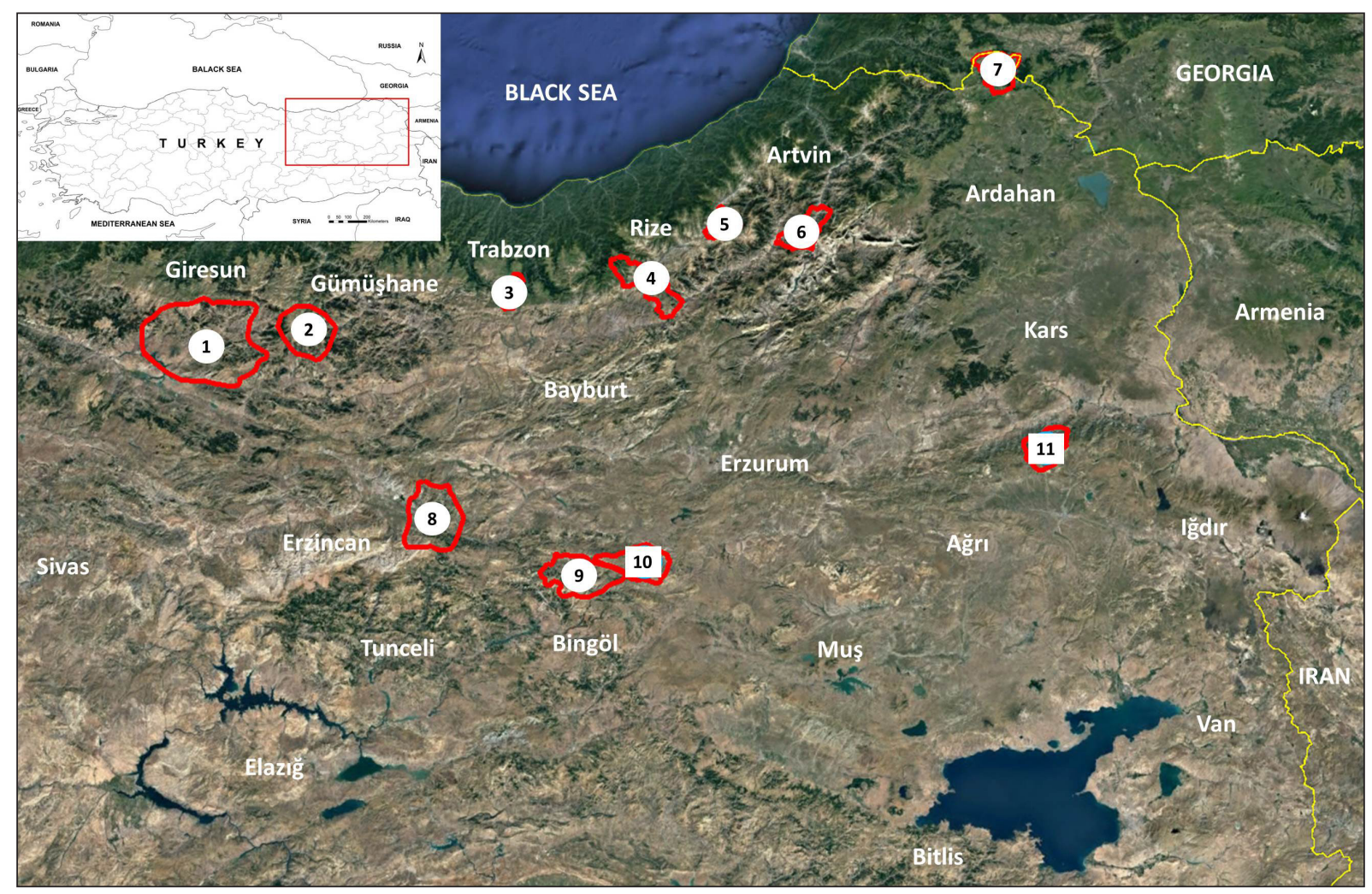

Fig. 1 - Sampling areas (Google Earth 2019). 


\section{TABLE 1}

Sampling areas.

\begin{tabular}{cllc}
\hline No. & Field Name & Province/District & Area $\left.\mathbf{( k m}^{\mathbf{2}}\right)$ \\
\hline 1 & Sarıçiçek Mountain (Mt.) & Giresun/Çamoluk, Alucra, Şebinkarahisar & 1.626 \\
2 & Gavur Mt. & Gümüşhane/Şiran,Torul and Giresun/Alucra & 433 \\
3 & Uzuntarla & Trabzon/Çaykara & 83 \\
4 & Ovit Mountain & Rize/İkizdere & 336 \\
5 & South of Kaçkar Mt. & Artvin/Yusufeli (part of Kaçkar Mt. National Park) & 123 \\
6 & Su Kavuşumu & Artvin/Yusufeli Wildlife Reserve Area (WRA) & 220 \\
7 & Sesödile Mt. & Ardahan/Posof WRA & 247 \\
8 & Sansa Strait & Erzincan/Üzümlü & 586 \\
9 & Yedisu Valley & Bingöl/Yedisu & 441 \\
10 & Çat WRA & Erzurum/Çat & 317 \\
11 & Kağızman WRA & Kars/Kağızman & 238 \\
Total & & & $\mathbf{4 . 6 5 0}$ \\
\hline
\end{tabular}

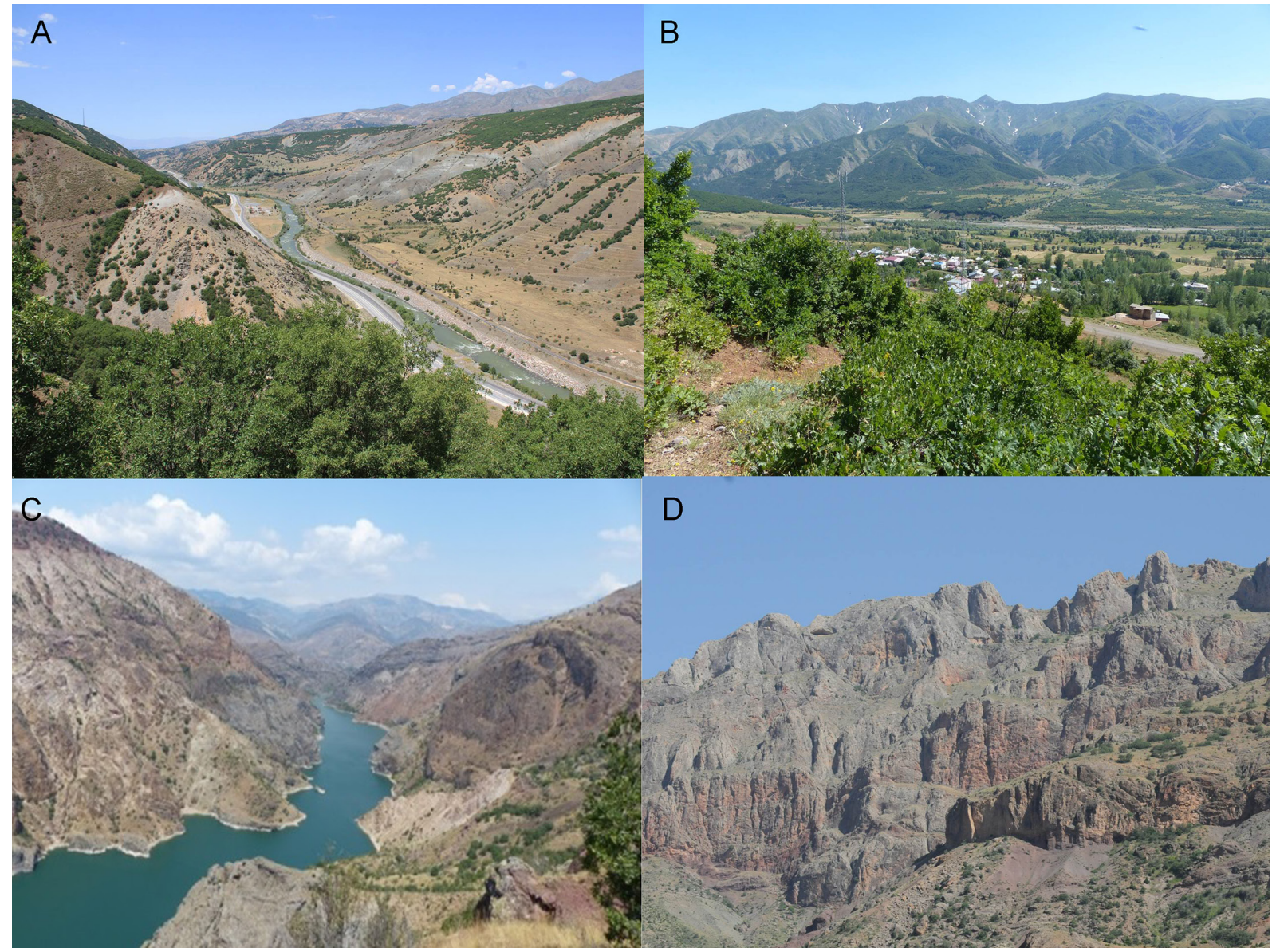

Fig. 2 - Preferred habitat of the Anatolian leopard in the study area. A. Sansa Strait. B. Yedisu Valley. C-D. Sariçiçek Mountain. 
Vegetation is sparse, reflecting the high desert conditions with cool to warm summers and cold winters. Vegetation is predominantly dry alpine steppe consisting of widely spaced shrubs or subshrubs, including astragals (Astragalus spp.), prickly thrift (Acantholimon spp.), wormwood (Artemisia spp.), and thyme (Thymus spp.). Alpine vegetation starts at 1800-2000 (-2500) meters. Most of the area has a continental climate. Winters are long and harsh, and summers short and hot. The annual mean temperature in this part of northeastern Anatolia is $5.7^{\circ} \mathrm{C}$. The coolest month is January $\left(-10.1^{\circ} \mathrm{C}\right)$, and the hottest is August $\left(20.8^{\circ} \mathrm{C}\right)$. Annual mean precipitation is about $38.7 \mathrm{~mm}$.

\section{Material}

Camera traps were first used to obtain photos and video images of the study areas. A total of 72 camera traps of various brands and models were used throughout the study. Thirteen of the camera traps took photos with flash at night, while 59 were capable of taking infrared photos and videos. During the remote information collection process, binoculars $(10 \times 42)$ and telescopes $(20-60 \times)$ of various brands were used. To photograph the periodical status of the area and the species seen during the field observations, various models of digital and video cameras were used. A $20 \mathrm{~cm}$ iron ruler was used to measure the tracks, scat diameters, and scratch marks obtained throughout the study; plastic sample containers with air-permeable writable areas ranging from 100 to $200 \mathrm{ml}$ were used to collect scats; locked plastic bags were used to collect other material evidence, such as hair and bone. Standing maps of sample areas obtained from Forest Management Plans (FMP) were also used to determine habitat types. ArcGIS 10.2, ArcMap software was used to process data and map and merge habitat types (ESRI 2013).

\section{Methods}

Northeastern Anatolia has multiple habitat types. Habitat categories were determined according to the European Nature Information System (EUNIS), a standard for classifying European habitats developed by the European Environment Agency (DAVIS et al. 2004; http://eunis.eea.europa.eu/), standing maps of sample areas obtained from Forest Management Plans (FMP) (GDF 2017), and field studies carried out by us. Initially, 28 habitat types were categorized and similar habitats were merged, such as forest for all forest functions. After the merging, we reduced these 28 habitat types to eight (1: Village centres (V); 2: Agriculture and pasture (AP); 3: Sparse Forest (SF); 4: Dense Forest (DF); 5: Subalpine Grassland (SG); 6: Alpine Grassland (> $1800 \mathrm{~m})(\mathrm{AG})$; 7: Rocky (R); 8: Riparian zones (Ri)) and categorized sightings of leopards and their tracks to determine their habitat uses (Table 2).

Leopard habitat was determined based on camera trap pictures, thermal video camera images, and signs of leopard presence (tracks, scats, scraping, scratching, urine, and food remains), which were recorded and collected during field trips (SMIth et al. 1989; KIABI et al. 2002; KHOROZYAN 2003; FARHADINIA 2009; GHODDOUsi et al. 2008; MONDAL et al. 2012; TAGHDISI 2013 et al.). Leopard trails were also followed to determine their activities within habitat types. Field studies to determine leopard habitat use were performed during all seasons at least twice in a month between April 2013 and December 2017, in total 321 days but less frequent in winter (Table 3 ).

Direct and indirect observation methods were used during the field studies. Direct observations were performed by one or two teams consisting of two people at a point or along a line. Direct observation of leopards was attempted with telescopes and binoculars or else, photos and video images were obtained with camera traps. For indirect observations, we looked for signs such as tracks, scat, scratching, scraping, urine, and food remains. All of the sampling areas were scanned by two to four people along a transect 20-50 meters apart, depending on the seasonal terrain. Following the field scanning, camera-traps were placed along established leopard trails on ridge tops and in deep valleys and river ecosystems to maximize capture probabilities over a large area. 


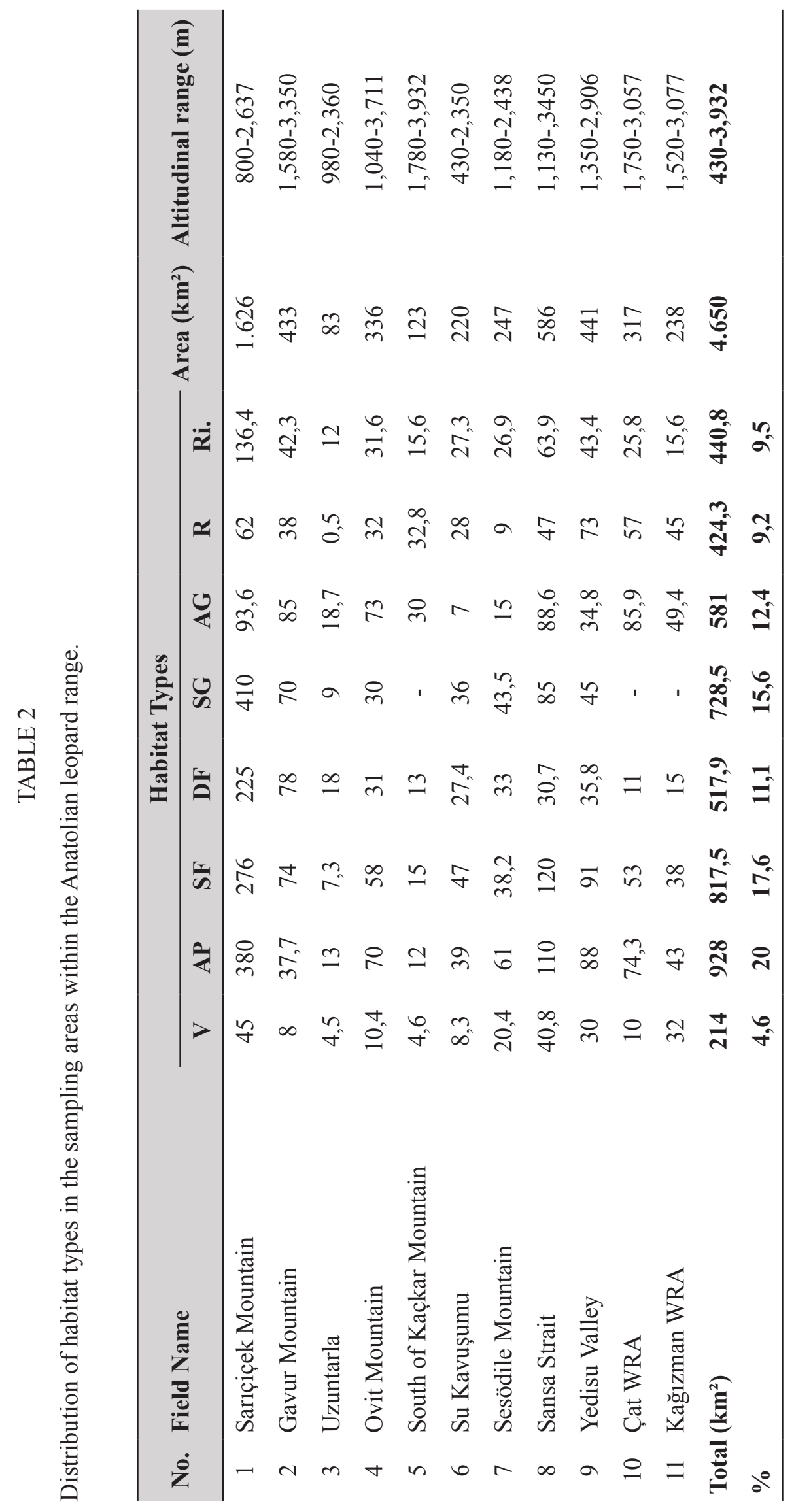


TABLE 3

Research points and number of visits by year.

\begin{tabular}{lcccccccccccc}
\hline Years & Giresun & Gümüşhane & Trabzon & Rize & Artvin & Ardahan & Erzincan & Bingöl & Erzurum Kars & Total \\
& $\mathbf{1}$ & $\mathbf{2}$ & $\mathbf{3}$ & $\mathbf{4}$ & $\mathbf{5 - 6}$ & $\mathbf{7}$ & $\mathbf{8}$ & $\mathbf{9}$ & $\mathbf{1 0}$ & $\mathbf{1 1}$ & (days) \\
\hline 2013 & 65 & 3 & 2 & 3 & - & 3 & - & - & 6 & 5 & 92 \\
2014 & 47 & - & 2 & - & 5 & - & - & - & - & - & 49 \\
2015 & 63 & - & - & - & 4 & - & - & 21 & - & - & 88 \\
2016 & 25 & - & 2 & 2 & - & - & - & - & - & - & 29 \\
2017 & 35 & - & - & 3 & - & - & 25 & - & - & - & 63 \\
Total & $\mathbf{2 5 0}$ & $\mathbf{3}$ & $\mathbf{6}$ & $\mathbf{8}$ & $\mathbf{9}$ & $\mathbf{3}$ & $\mathbf{2 5}$ & $\mathbf{2 1}$ & $\mathbf{6}$ & $\mathbf{5}$ & $\mathbf{3 2 1}$ \\
\hline
\end{tabular}

We placed camera traps based on the design described by KARANTH (1995) and YORK et al. (2001), side by side at randomly chosen trapping sites between May 2013 and December 2017. The areas where camera traps were placed in the sampling areas were hidden to not disturb the local people or cause conflicts between the local people and leopards. The camera trap models that flash at night were believed to make the leopards and people living in the region uneasy; therefore, infra-red, remote-trip digital camera units were mostly used. Other sampling areas in the study area were visited 40 times; all direct and indirect signs of leopards were investigated, but no camera traps were placed. Also, thermal video camera images taken during field scanning activities carried out by the Turkish military within the sampling areas were obtained, and local people, including the shepherds who live in the vicinity of the study area, were consulted.

The only other predator cat species in sampling areas is the Eurasian lynx (Lynx lynx). Their tracks are similar to those of the Anatolian leopards, but can be distinguished by the shape and size of their fingers. Yet, to avoid any possible confusion, the tracks $9 \mathrm{~cm}$ and longer were considered to belong to the Anatolian leopards and those 5-6.5 cm long were considered to belong the Eurasian lynx (GREEN 1991; RICHARDSON 1992; VAN MAANEN 2006). Similarly, scat that was thought to belong to the Anatolian leopards was collected from the study areas and preserved. The Eurasian lynx and grey wolf (Canis lupus) scats could be confused with those of leopards, and physical parameters such as colour, weight, and diameter were used to distinguish among the scats of these three species. To avoid any possible confusion, segmented-shaped scats found in the vicinity of leopard tracks and with a mean diameter of $\sim 2.7 \mathrm{~cm}$, pointed ends and many lobes were considered to belong to leopards (LUKAREVSKY 2001; KHOROZYAN \& MALKHASYAN 2002; KHOROZYAN 2003).

\section{Results}

Of the thousands of photographs and video recordings analysed, six camera trap pictures of Anatolian leopards were obtained from Sarıçiçek Mountain (Çamoluk/Giresun) in 2013 and three thermal video camera images were obtained by Turkish military from Yedisu Valley (Yedisu/Bingöl) in 2015 and Sansa Strait (Üzümlü/Erzincan) in 2017 (Fig. 3).

In addition to the images, the following were found: 28 sets of tracks $9-12 \mathrm{~cm}$ in diameter, 13 pieces of scat exceeding $3 \mathrm{~cm}$ in diameter, two ground-scraping $15-20 \mathrm{~cm}$ wide and 30-50 cm long, and three tree scratches $90-200 \mathrm{~cm}$ high on juniper and hawthorn trees (Fig. 4).

During the study, a total of 58 pieces of data were recorded: six camera trap pictures, three thermal video camera images, 28 sets of tracks, 13 pieces of scat, two ground-scrapings, three tree-scratches, and three reports by local people (Table 4). 


\section{TABLE 4}

Number of signs of the Anatolian leopard presence in each habitat type $(\mathrm{CT}=$ Camera Trap; TC $=$ Thermal Camera; $\mathrm{T}=$ Track; $\mathrm{S}=$ Scat; Scr. $=$ Scraping; Stc. $=$ Scratching).

\begin{tabular}{|c|c|c|c|c|c|c|c|c|}
\hline \multirow{2}{*}{ No. } & \multirow{2}{*}{ Field Name } & \multirow{2}{*}{ Habitat types } & \multicolumn{6}{|c|}{ Record type and number } \\
\hline & & & CT & TC & $T$ & $\mathbf{S}$ & Scr. & Stc. \\
\hline \multirow{7}{*}{1} & \multirow{7}{*}{ Sarıçiçek Mountain } & Agriculture and pasture & - & - & 2 & 3 & - & 1 \\
\hline & & Sparse forest & 3 & - & 4 & 3 & 1 & 1 \\
\hline & & Dense forest & - & - & 2 & - & - & - \\
\hline & & Subalpine grassland & 1 & - & 1 & 2 & - & - \\
\hline & & Alpine grassland & - & - & 1 & 1 & 1 & 1 \\
\hline & & Rocky & 2 & - & 2 & 2 & - & - \\
\hline & & Riparian zones & - & - & 4 & - & - & - \\
\hline 2 & Gavur Mountain & Rocky & - & - & 1 & - & - & - \\
\hline 3 & Uzuntarla & Dense forest & \multicolumn{6}{|c|}{ Reported by local people } \\
\hline 4 & Ovit Mountain & Sparse forest & - & - & 2 & - & - & - \\
\hline 5 & South of Kaşgar Mt. & Rocky & - & - & 1 & 1 & - & - \\
\hline 6 & Su Kavuşumu & Riparian zones & - & - & 1 & - & - & - \\
\hline 7 & Sesödile Mountain & Sparse forest & \multicolumn{6}{|c|}{ Reported by local people } \\
\hline \multirow{2}{*}{8} & \multirow{2}{*}{ Sansa Strait } & Agriculture and pasture & - & 1 & - & - & - & - \\
\hline & & Riparian zones & - & 1 & - & - & - & - \\
\hline \multirow{4}{*}{9} & \multirow{4}{*}{ Yedisu Valley } & Village center & - & - & 1 & - & - & - \\
\hline & & Agriculture and pasture & - & - & 2 & - & - & - \\
\hline & & Sparse forest & - & 1 & 1 & 1 & - & - \\
\hline & & Riparian zones & - & - & 2 & - & - & - \\
\hline 10 & Çat WRA & Subalpine grassland & - & - & 1 & - & - & - \\
\hline 11 & Kağızman WRA & Subalpine grassland & \multicolumn{6}{|c|}{ Reported by local people } \\
\hline
\end{tabular}
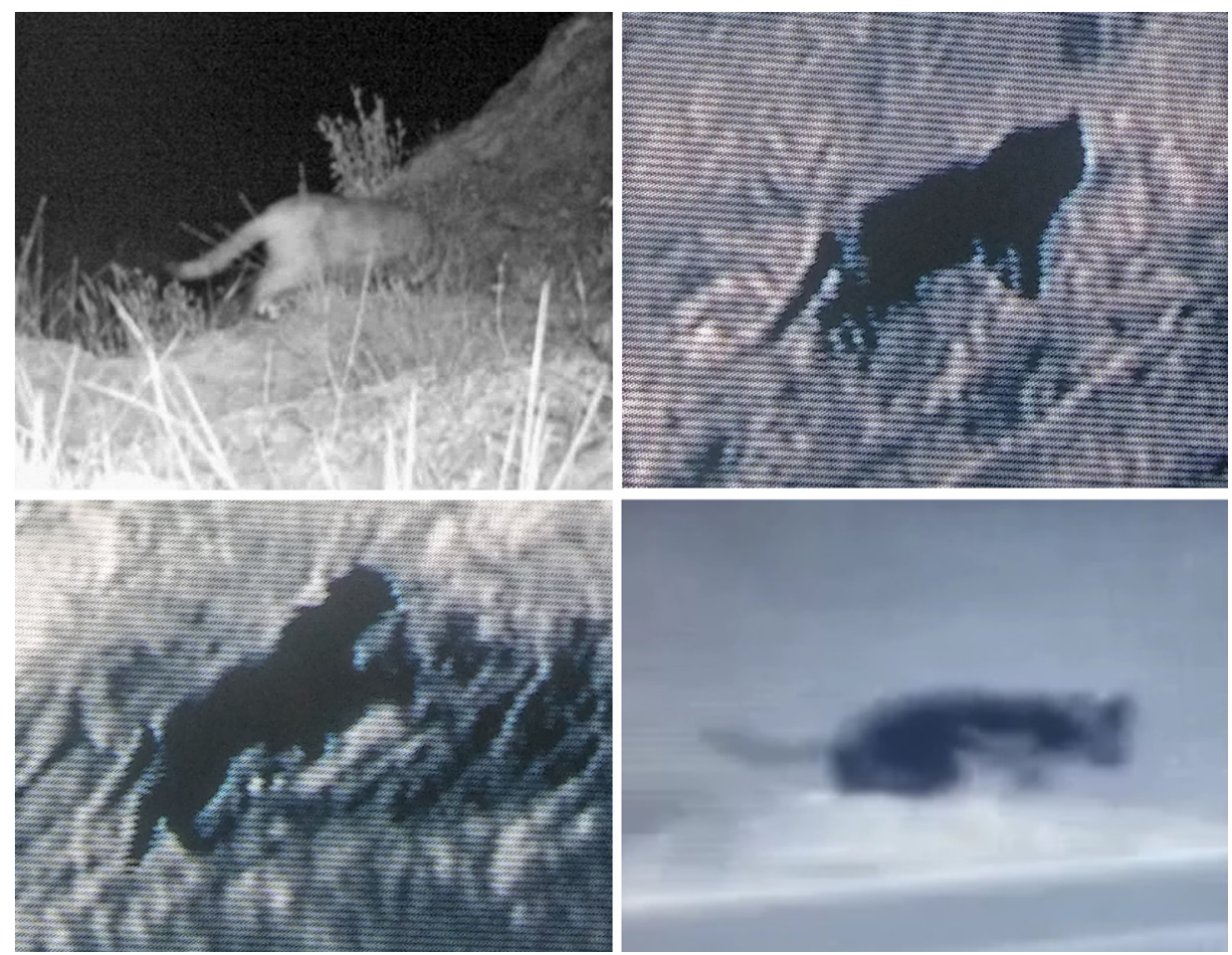

Fig. 3 - Camera trap picture and thermal video camera images of Anatolian leopards. 
Our results suggest that, of the habitat types in the sampling areas, the most leopard evidence was found in sparse forest areas $(31.1 \%)$, followed by rocky areas $(15.5 \%)$, agriculture and pasture areas $(15.5 \%)$, riparian zones $(13.8 \%)$, subalpine grassland $(10.3 \%)$, alpine grassland $(6.9 \%)$, dense forest $(5.2 \%)$, and village centres $(1.7 \%)$. The elevations where the findings were obtained in the present study are directly proportional to the geographic location of the sampling areas and are all over 1000 meters. The lowest elevation was 1176 meters - in the Sansa Strait - while the highest was 3050 meters - in the Ovit Mountain. Of the 58 data points obtained during the study, 49 were from the south aspect. Indirect signs (tracks, scats, and scraping) were also found in the north aspect.

Three areas obtained extensive camera trap, and field observation findings during the study were evaluated separately in terms of their habitat conditions. Sarıçiçek Mountain obtained the most data, 38 pieces, 33 of which were obtained from the south aspect. Data from Sarıçiçek Mountain were obtained in sparse forest areas $(31.6 \%)$, rocky areas $(15.8 \%)$, agriculture and pasture areas $(15.8 \%)$, subalpine grassland $(10.5 \%)$, alpine grassland (10.5\%), riparian zones $(10.5 \%)$, and dense forest $(5.3 \%)$ habitats. In these areas, the Anatolian leopards prefer the regions close to water resources in the high parts of the mountains covered with meadows and sparse mixed forests and areas dominated by brush and shrubs, including hawthorn (Crataegus monogyna), rhododendron (Rhododendron spp.), dog rose (Rosa canina), Caucasian whortleberry (Vaccinium arctostaphylos), astragal (Astragalus spp.), prickly thrift (Acantholimon spp.), wormwood (Artemisia spp.), and thyme (Thymus spp.). The dominant trees in this area are Scotch pine (Pinus sylvestris), juniper ((Juniperus communis, J. oxycedrus, J. foetidissima, J. excelsa), oak (Quercus petraea, Q. pubescens, Q. robur, Q. coccifera, Q. hartwissiana), birch (Betula pendula), beech (Fagus orientalis), poplar (Populus tremula, P. nigra) and willow (Salix fragilis, S. alba, S. triandra). During the study, eight data points were obtained in the Yedisu Valley, all in the south aspect. All data in the Yedisu Valley were obtained from sparse forest areas (37.5\%), agriculture and pasture areas $(25 \%)$, riparian zones $(25 \%)$, and village centre habitats $(12.5 \%)$. Vegetation is predominantly dry alpine steppe consisting widely of brush, spaced shrubs or subshrubs, including hawthorn, European mountain ash (Sorbus aucuparia), oleaster-leafed pear (Pyrus elaeagnifolia), dog rose, astragals, prickly thrift, wormwood, and thyme. The dominant tree species in these areas are oak (Quercus petraea, Q. pubescens, Q. robur, $Q$. infectoria, Q. brantii, Q. hartwissiana), juniper (Juniperus communis, Juniperus excelsa), poplar (Populus tremula), Scotch pine and willow (Salix alba, S. exelsa, S. triandra). We used two thermal camera images obtained by Turkish military within the Sansa Strait. One of them was from agriculture and pasture areas and the other from a riverside covered with meadows and areas dominated by shrubs. The dominant tree species in these areas are willow (Salix alba, S. exelsa, S. triandra), poplar (Populus euphratica, P. nigra, P. alba), oak (Quercus petraea, Q. pubescens, Q. robur, Q. infectoria), juniper (Juniperus communis, J. oxycedrus, J. foetidissima, J. excelsa), and Scotch pine. Maps showing habitat type and the data obtained from these three areas are shown in Fig. 5.
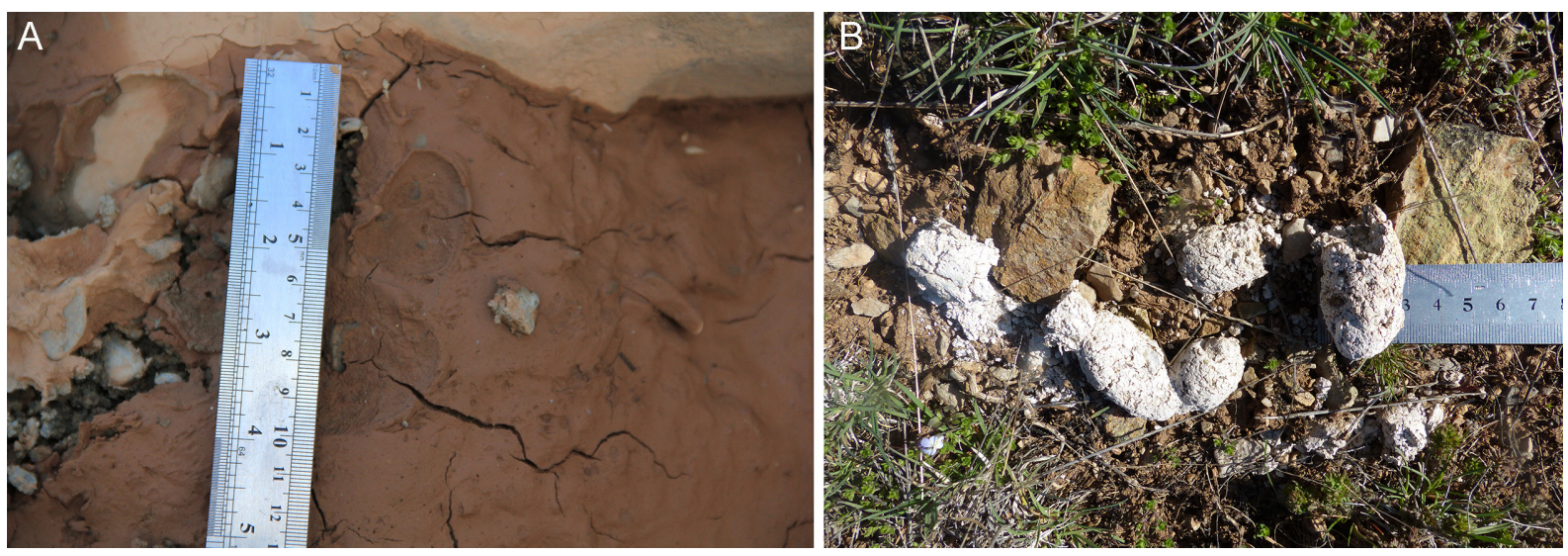

Fig. 4 - A. Anatolian leopard track. B. Anatolian leopard scat. 
When the maps were examined, many habitats similar to the sampling areas obtained from the data were also found in all three provinces.

As a result of our field observations and counts conducted in all sampling areas during this study, populations of large prey species that constitute the food sources of the Anatolian leopards were also evaluated. We also found that population densities of large prey species constituting leopard food sources were more than enough available in all the study areas to attract leopards. One example of population density attracting leopards is the density of wild goats and boars, the main food sources for leopards in Sarıçiçek Mountain. The field studies carried out in this area revealed around one hundred wild goats, 20-30 wild boars, and abundant European hares. The study determined that the wild boar and goat species in the sampling areas were probably more important food species for leopards. Also, the number of stray dogs in the Yedisu Valley was found to be relatively higher than in the other sampling areas. The major prey species preferred by leopards over the year were the wild boar (Sus scrofa), wild goat (Capra aegagrus), chamois (Rupicapra rupicapra), roe deer (Capreolus capreolus), and European hare (Lepus europaeus); all of these are abundant in the habitats that leopards use (Table 5).

We collected less data on the habitat use of leopards in the winter due to harsh winter conditions and transportation difficulties in the study areas. For a species that can survive in all kinds of terrain and climate conditions such as the leopard, habitat use in the winter is directly proportional to the distribution of food sources, as in the summer months.

These important data revealed the presence of the Anatolian leopard populations in different habitats in the study area. Most of the findings obtained during the study were in areas very close to village centres.
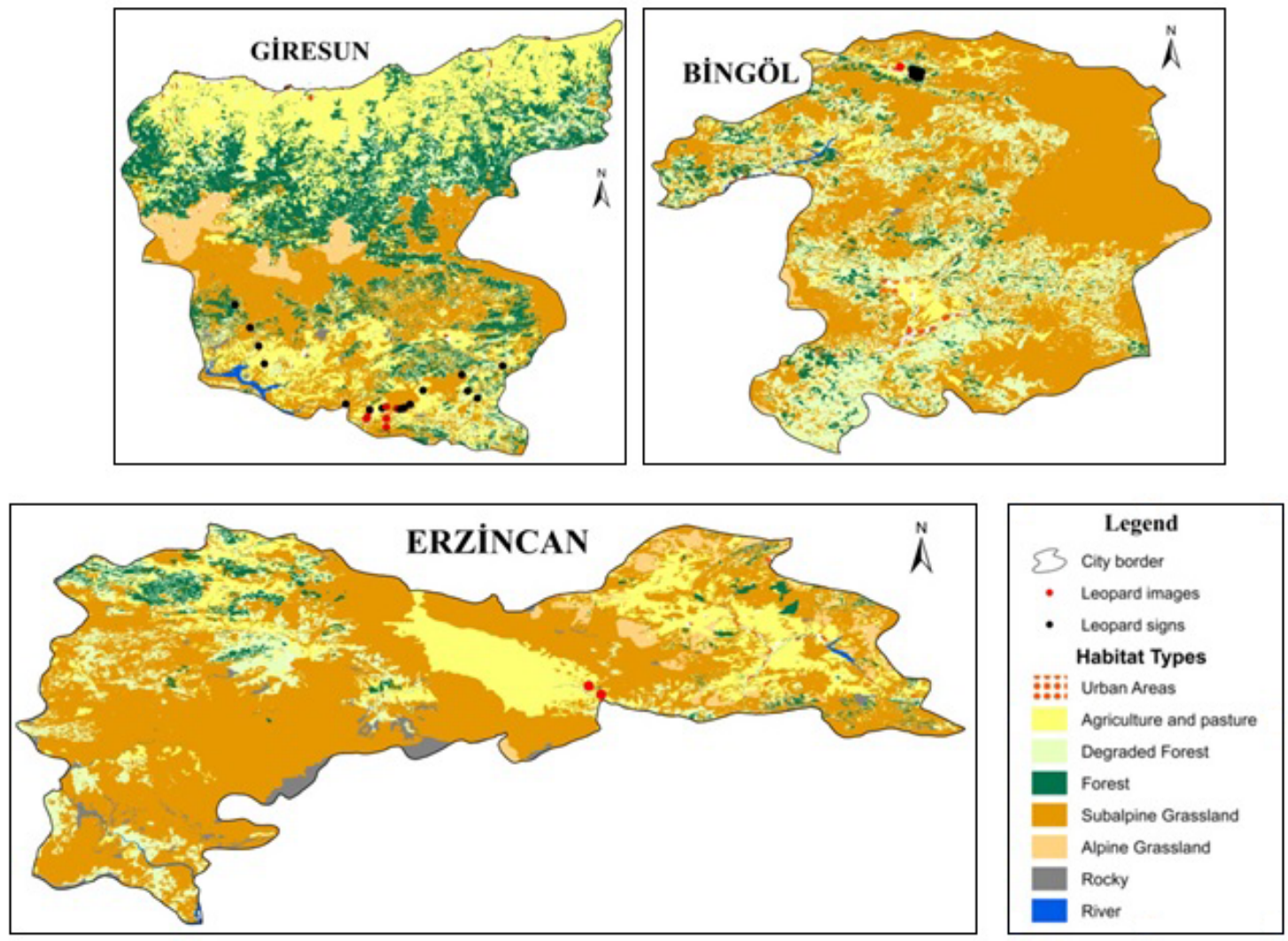

Fig. 5 - Distribution of habitat types and the data obtained from three sampling areas across the province. 
TABLE 5

Distribution of the Anatolian leopard prey species in the sampling areas.

\begin{tabular}{|c|c|c|}
\hline No. & Field Name & Prey Species \\
\hline 1 & Sarıçiçek Mountain & Wild boar - Wild goat - Roe deer - European hare \\
\hline 2 & Gavur Mountain & Wild boar - Chamois - Wild goat - Roe deer - European hare \\
\hline 3 & Uzuntarla & Wild boar-Roe deer - European hare \\
\hline 4 & Ovit Mountain & Wild boar - Chamois - Wild goat - Roe deer - European hare \\
\hline 5 & South of Kaçkar Mt. & Chamois - Wild boar - Wild goat - Roe deer - European hare \\
\hline 6 & Su Kavuşumu & Wild goat - Wild boar - Chamois - Roe deer - European hare \\
\hline 7 & Sesödile Mountain & Wild boar - Roe deer - European hare \\
\hline 8 & Sansa Strait & Wild boar - Wild goat - European hare \\
\hline 9 & Yedisu Valley & Wild boar - Wild goat - Chamois - Stray dogs - Roe deer - European hare \\
\hline 10 & Çat WRA & Wild boar - Chamois - Wild goat - European hare \\
\hline 11 & Kağızman WRA & Wild boar - Wild goat - Chamois - Roe deer-European hare \\
\hline
\end{tabular}

Despite this, local people living in the research area had little information about leopards. The reason for this is thought to be the animal's mysterious and nocturnal character, low density, and abundance of prey and wide-area usage of leopards. The people who gave accurate information about leopards were those who were over middle age and interested in hunting.

Throughout the study, many other species of wild animals that directly affected the Anatolian leopard were found in the study areas. A prominent finding of this study is that high densities of other predator species detract leopards, as they compete with them and threaten them or their cubs. It was observed that species such as grey wolves, brown bears, and the Eurasian lynx pressure leopard cubs in sampling areas.

The most important factor threatening the Anatolian leopard populations was found to be a lack of information on species, illegal hunting, habitat loss, predatory repression, all forestry activities not considering wildlife, roads, agricultural drugs, environmental pollution, unplanned and excessive grazing, and unplanned plateau activities.

\section{Discussion}

To date, many studies have been conducted to determine leopards' habitat use and population density in the Caucasian ecological area and its vicinity based on camera trap pictures, tracks, and fecal distribution (KHOROZYAN 2003; GHODDOUSI et al. 2008; FARHADINIA et al. 2009; MONDAL et al. 2012; TAGHDISI et al. 2013). We believe that camera trap pictures and indirect signs represent accurate data, and therefore employed this technique in the present study. However, different ecological conditions and changes in the biology of species may cause errors in the results, especially because evaluating population density based on indirect signs is not a sound method.

Some resources argue that leopards have gone extinct in Turkey, especially in the study area; several researchers even argue that their overall population size is not large enough to continue the species (KHOROZYAN et al. 2006; LUKAREVSKY et al. 2007; ZIMMERMAN et al. 2007). However, this study found that the leopard has not gone extinct in Turkey; on the contrary, it has survived without any protection efforts, and populations of different sizes can be found in various habitats far from each other. 
Although TURAN (1984) and DEMIRSOY (1996) stated that the Eastern Black Sea region is not part of the distribution of the leopard in Turkey and that no sight records were reported in this region, both a literature review and the present study have recorded several leopards in the region over the last fifty years. Furthermore, Kumerloeve (1956), Huş (1967), GÜRPInAR (1974), GoOdwIN \& HollowaY (1978), BAŞKAYA \& BILGILI (2004), and ARPACIK (2018) reported the Eastern Black Sea region - where there are leopard populations of different sizes - to be a leopard habitat. BAŞKAYA \& BILGILI (2004) presented the leopard's distribution with coordinates in the Eastern Black Sea Mountains. We found signs of leopard in the same areas, including Ovit Mt., Kaçkar Mt., and Su Kavuşumu.

LUKAREVSKY et al. (2007) did not confirm the presence of leopards in northeastern Anatolia during their field trip to the Turkish part of the Caucasus eco-region. Also, using ecological niche modelling and MaxEnt program, ZIMMERMANN et al. (2007) predicted the distribution of the leopard in the ecological region of the Caucasus, arguing that this region is potentially suitable for the leopard, and that more studies should be conducted on the eastern borders of Turkey.

Some researchers have stated that the main determinant factor of leopard habitat use is the abundance and easy availability of prey (KHOROZYAN et al. 2003; BAŞKAYA \& BILGILI 2004; MEIJAARD \& NOTES 2004; BAILEY 2005; LUKAREVSKY et al. 2007), and this is consistent with the results of this study. Food sources, water resources, and nesting areas were the most important indicators of leopard habitat use. According to BAILEY (1993) and JOHANY (2006), leopards can be found in many habitats, but water resources are critical for the species. The habitats of leopard prey mostly involve water resources, and therefore so do those of the leopards.

Studies of places close to the sampling areas show that the most critical habitats for leopards are degraded forest areas, areas dense with bushes, and rocky areas (KHOROZYAN \& MALKHASYAN 2002; KHOROZYAN 2003; LUKAREVSKY et al. 2007; GHODDOUSI et al. 2008; TAGHDISI et al. 2013). The fact that this study detected leopards in degraded forest areas, rocky areas, and riparian ecosystems, subalpine and alpine grasslands is consistent with other studies carried out close to our study region. We identified three reasons why leopards may live in these habitats: their diet consists mostly of animals in these areas, leopards nest, and the presence of many caves in this area where leopards can hide. However, records in Turkey show that leopards can easily survive in all forest communities (coniferous, leafy, mixed forest, meadow, etc.) and at different elevations (KUMERLOEVE 1956; Hus 1967; BORNER 1977; TURAN 1984; DEMIRSOY 1996). Because the species can easily adapt to its environment, this finding indicates that vegetation and elevation are indirectly important for the species' ecological needs. Of the 58 data points obtained during the study, 49 were from the southerly aspect. Indirect signs (tracks, scats, and scraping) were also found in the northerly aspect. The reason why most of our findings were from the southerly aspect is that this is where most leopard prey is found. The temperature changes over the day due to their continental climate of the sampling areas, especially the exposure of the rocky surfaces in the southerly aspect, which made this aspect more attractive for the leopard. Reliable data related to the habitat use of leopards could not be obtained in the winter months due to harsh weather and transportation difficulty. However, since the species constituting the diet of the leopard winter in the forested areas at lower elevations with higher temperatures, it is quite likely that leopards can be found at these points. The main conclusion that can be drawn from these ecological findings is that the habitats of the prey species and the use of these habitats by the prey are two of the most important factors for determining habitats for a species like a leopard that can easily adapt to environments and prey.

According to EDGAONKAR \& CHELlAm (1998), the leopard is more active in areas without human pressure. However, all of the data obtained in the study were obtained in areas very close to human village centres. The image of the individual leopard identified in the Yedisu Valley was obtained $1 \mathrm{~km}$ 
from a district centre, in a region that people frequently use for transportation. Nevertheless, almost none of the local people were aware that there were leopards in the area. This is due to the species' wide habitat use, nocturnal and timid character.

According to many studies, the leopard has a distribution of up to 4000 meters above sea level (GREEN 1991; JOHANY 2006). All of the areas where the findings of the leopard were obtained in this study are $>1000$ meters above sea level. The reason for this is the geographic location of the study areas. We believe that future scientific studies at lower elevations and in areas suitable for leopard habitat use will find evidence that the species is present. The main threats to leopards both in our region and around the world are habitat loss and illegal hunting (BAILEY 1993; NOWELL \& JACKSON 1996; KHOROZYAN 2003; FARHADINIA 2009; GHODDOUSI et al. 2008; MONDAL et al. 2012; TAGHDISI et al. 2013). Besides, people are sceptical as to whether leopards exist in northeastern Anatolia and it makes conservationdevelopment studies more difficult in this region than in surrounding regions.

In the fall, illegal hunting of food sources and competition with other predatory species has been shown to decrease populations of predators similar to the leopard (FARHADINIA et al. 2009; GHODDOUSI et al. 2008; MondAL et al. 2012; TAGHDISI et al. 2013). Illegal hunting and an excess of other predatory species like grey wolves, brown bears, and the Eurasian lynx with which leopards compete, pose significant threats to the survival of leopards in Turkey.

The present study investigated the habitat use of the Anatolian leopard in northeastern Anatolia and found different settled populations of leopard. Humans are constantly destroying leopard habitats to fit their own needs, and this threatens the survival ability of a species that is important to biodiversity in Turkey. Almost all of the threats are directly related to the increasing human population, and they create serious pressures on both leopards and the species they hunt.

Measurements need to be taken against these threats, such as:

- awareness-raising activities in areas where the leopard is distributed;

- prevention of illegal hunting activities;

- prevention of activities that will divide the habitats of wild animals and cause habitat losses, and reconnection of the divided habitats;

- better control of predatory populations;

- considering wildlife when carrying out forestry activities;

- building wild animal crossings (bridges, culverts, underpasses, and overpasses) across inappropriate parts of the roads dividing the habitats of wild animals. On the roads leading to important sites for wild animals and in the vicinity of these roads, speed limits should be imposed, horns should not be honked, loud music should not be played, and information should be given on the important species of the region;

- planning and controlling of grazing activities in areas intensively used by leopards and their prey;

- carrying out transhumance activities in appropriate areas, away from the areas intensively used by leopards and their prey. These areas should be defined by relevant institutions;

- careful control of livestock grazing to prevent possible leopard-human conflict.

All the data obtained from this study provide basic information about the leopards' ability to survive in Turkey to date have important implications for Turkey's wildlife and future studies to be carried out for the recognition and protection of the species. 


\section{Acknowledgements}

This manuscript is a part of a $\mathrm{PhD}$ thesis written by AS. This research received no specific grant from any funding agency or commercial or not-for-profit sectors. We would also like to thank Turkish Military and Security Forces for whom we provided thermal camera images, which contributed immensely to this study.

\section{References}

ARPACIK A. (2018). Breeding Status and Diet of Leopard (Panthera pardus) in Eastern Karadeniz Mountains. PhD Thesis. K.T.Ü. Graduate School of Natural and Applied Sciences, Department of Forest Engineering, Trabzon.

Bailey T.N. (1993). The African Leopard. Ecology and Behaviour of a Solitary Felid. Colombia University Press, New York.

BAILey T.N. (2005). The African Leopard: Ecology and Behaviour of a Solitary Felid. (2 ${ }^{\text {nd }}$ Ed.), Blackburn Press, Caldwell, New Jersey.

BAŞKAYA Ş. \& BILGILI E. (2004). Does the leopard Panthera pardus still exist in the Eastern Karadeniz Mountains of Turkey? Oryx 38 (2): 228-232.

BORNER M. (1977). Leopards in Western Turkey. Oryx 14: 26-30.

Bothma J.D.P. \& LE Riche E.A.N. (1989). Evidence of a flexible hunting technique in Kalahari leopards. South African Journal of Wildlife Research 19 (2): 57-60. Available from https://hdl.handle.net/10520/AJA03794369_1426 [accessed 16 September 2020].

CAN E. (2004). Status, Conservation and Management of Large Carnivores in Turkey. Report on behalf of the Standing Committee of the Convention on the Conservation of European Wildlife and Natural Habitats 28, Strasbourg.

DAvis C.E., Moss D. \& HILl M.O. (2004). EUNIS Habitat Classification 2004. European Environment Agency, Copenhagen.

Demirsoy A. (1996). Turkey's Vertebrates - Mammalians. Ministery of environmental Protection, General Directorate of Environmental Protection Publications, Ankara, Republic of Turkey.

Edgaonkar A. \& Chellam R. (1998). A Preliminary Study on the Ecology of the Leopard (Panthera pardus fusca) in Sanjay Gandhi National Park, Maharashtra. Wildlife lnstitute of India, New Delhi.

EdgaonKar A. \& Chellam R. (2002). Food habit of the leopard (Panthera pardus) in Sanjay Gandhi National Park, Maharastra, India. Mammalia 2002: 353-360.

ESRI (2013). ArcGIS version 10.2 ArcGIS Desktop: Release 10. Redlands, CA: Environmental Systems Research Institute.

Farhadinia M.S., Nezami B., Hosseini-Zavarei F. \& Valizadeh M. (2009). Persistence of Persian leopard in a buffer habitat in North-eastern Iran. Cat News 51: 34-36.

GDF (2017). Management plan of Forest planning units between 2011-2020 (Forest Regional Directorate; Artvin, Elazı̆̆, Erzurum, Giresun, Trabzon). Ministry of Agriculture and Forestry, General Directorate of Forestry, Ankara, Republic of Turkey.

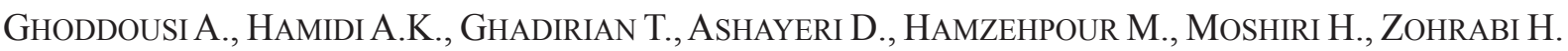
\& JULAI L. (2008). Territorial marking by Persian leopard in Bamu National Park, Iran. Zoology in the Middle East 44: 101-103. https://doi.org/10.1080/09397140.2008.10638293 
Goodwin H.A. \& Holloway C.W. (1978). Red Data Book, IUCN Survival Service Commission. Mammalia 1.

Green R. (1991). Wild Cat Species of the World. Basset Publications, Plymouth.

GÜRPINAR T. (1974). Anatolian Leopard. The Journal of Hunting 1: 7-14.

HamiLton P.H. (1976). The Movements of Leopards in Tsavo National Park, Kenya, as determined by Radio-Tracking. MSc Thesis, University of Nairobi.

Hayward M.W. \& Kerley G.I.H. (2005). Prey preferences of the lion (Panthera leo). Journal of Zoology 267: 309-322. https://doi.org/10.1017/S0952836905007508

Hopcraft J.G.C., Sinclair A.R.E. \& PACKer C. (2005). Planning for success: Serengeti lions seek prey accessibility rather than abundance. Journal of Animal Ecology 74: 559-566. https://doi.org/10.1111/j.1365-2656.2005.00955.x

Huș S. (1967). Game Animals and Hunting. Istanbul University, Faculty of Forestry Publications 202: 406.

JOHANY A.M.H. (2006). Distribution and conservation of the Arabian leopard in Saudi Arabia. Journal of Arid Environments 68: 20-30. https://doi.org/10.1016/j.jaridenv.2006.04.002

KARANTH K.U. (1995). Estimating Tiger (Panthera tigris) populations from Camera trap data using capture-recapture models. Biological Conservation 71: 333-338.

https://doi.org/10.1016/0006-3207(94)00057-W

KhOROZYAN I. (2003). Camera Photo-Trapping of Endangered Leopards (Panthera pardus) in Armenia: a Key Element of Specific Status Assessment. Final Report to People's Trust for Endangered Species, London, UK.

KHOROZYAN I. \& MALKHASYAN A. (2002). Ecology of the leopard (Panthera pardus) in Khosrov Reserve, Armenia: Implications for conservation. Scientific Reports of Societa Zoologica "La Torbiera" 6: $1-41$.

KHOROZYAN I., BARYSHNIKHOV G.H. \& ABRAMOV A.V. (2006). Taxonomic status of the leopards in the Caucaus and adjacent areas. Russian Journal of Theriology 5 (1): 41-52.

Kiabi B.H., Dareshouri B.F., Ghaemi R.H. \& Jahanshahi M. (2002). Population Status of the Persian Leopards in Iran. Zoology in the Middle East 26: 41-47.

Kitchener A.C., Breitenmoser-Würsten C.H., Eizirik E., Gentry A., Werdelin L., Wilting A., Yamaguchi N., Abramov A.V., Christiansen P., Driscoll C., Duckworth J.W., Johnson W., Luo S.J., Meijaard E., O’Donoghue P., Sanderson J., Seymour K., Bruford M., Groves C., Hoffmann M., Nowell K., Timmons Z. \& Tobe S. (2017). A Revised Taxonomy of the Felidae. The Final Report of the Cat Classification Task Force of the IUCN/SSC Cat Specialist Group. Cat News, Special Issue $11: 1-80$.

Kumerloeve H. (1956). Zur Verbreitung des Leoparden (Panthera pardus) in Anotolien. Der Zoologische Garten 154-162.

LUKAREVSKY V.S. (2001). Leopard, Striped Hyena and Wolf in Turkmenistan. Signar, Moscow.

Lukarevsky V.S., AkKiev M., Askerov E., Agili A., CAn E., Guriedlidze Z., Kudaktin A.N., MALKhasyan A. \& YAROvenKo Y.A. (2007). Status of the leopard in The Caucasus. Cat News, Special Issue $2: 15-21$.

MEIJAARD E. \& Notes A. (2004). Biogeographic history of the Javan leopard Panthera pardus based on a craniometric analysis. Journal of Mammalogy 85 (2): 302-310. https://doi.org/10.1644/BER-010 
Mondal K., SANKAR K., QuREShi Q., GuPTA S. \& ChOURASIA P. (2012). Estimation of population and survivorship of leopard through photographic capture-recapture sampling in Western India. World Journal of Zoology 7( 1): 30-39.

Nowell K. \& JaCKson P. (1996). Wild Cats: Status, Survey and Conservation Action Plan. Gland, Switzerland; IUCN/ Species Survival Commission Cat Specialist Group.

RichARDSON D. (1992). Big Cats. Whitted Books, London.

Smith J.L.D., McDougal C. \& MiQuelle D. (1989). Scent marking in free-ranging tigers, Panthera tigris. Animal Behaviour 37: 1-10. https://doi.org/10.1016/0003-3472(89)90001-8

SUNQUist M.E. \& SUNQUisT F. (2002). Wild Cats of the World: 318-343. University of Chicago Press, London.

Taghdisi M., Mohammadi A., Nourani E., Shokri S., Rezaei A. \& Kaboli M. (2013). Diet and habitat use of the endangered Persian leopard in North-eastern Iran. Turkish Journal of Zoology 37: 1-8.

TURAN N. (1984). Turkey's Hunting Animals - Mammalians. GDF, Ankara.

UlLRICH B. (1994). Neue Gefahren für die letzten Leoparden der Türkei. Zoologische Gesellschaft für Arten- und Populationsschutz 1: 1-45.

VAN MAANEN E. (2006). Guide for distinguishing leopard signs from those of other co-existing large carnivores for Asia minor and the Caucasus. Anatolian Leopard Foundation (version 221208): 1-25.

York E.C., Moruzzi T.L., Fuller T.K., Organ J.F., Sauvajot R.M. \& DeGraAF R.M. (2001). Description and evaluation of a remote camera and triggering system to monitor carnivores. Wildlife Society Bulletin 29: 1228- 1237. Available from https://www.jstor.org/stable/3784148 [accessed 16 September 2020].

ZimMERMAN F., LUKAREVSKY V.S., BERUCHASVILi G., BREITENMOSER-WÜRSTEN C. \& BREITENMOSER U. (2007). Mapping the vision - potential living space for the leopard in the Caucasus. Cat News, Special Issue 2: 28-33.

Manuscript received: 27 February 2020

Manuscript accepted: 14 September 2020

Published on: 18 September 2020

Branch editor: Zjef Pereboom 